\title{
Evaluation of treatment of the exacerbation of asthma and wheezing in a pediatric emergency department
}

Drancisco de Assis Pereira Filho'

(iD) Roseli Oselka Saccardo Sarni²

(iD) Neusa Falbo Wandalsen ${ }^{3}$

\begin{abstract}
1. Professor Afiliado da Disciplina de Clínica Pediátrica do Departamento de Pediatria do Centro Universitário Saúde $A B C$, FMABC, Santo André, SP, Brasil. 2. Professora Titular da Disciplina de Clínica Pediátrica do Departamento de Pediatria do Centro Universitário Saúde ABC, FMABC, Santo André, SP, Brasil. 3. Professora Assistente da Disciplina de Clínica Pediátrica do Departamento de Pediatria do Centro Universitário Saúde ABC, FMABC, Santo André, SP, Brasil.
\end{abstract}

http://dx.doi.org/10.1590/1806-9282.66.9.1270

\section{SUMMARY}

OBJECTIVES: To evaluate the treatment of wheezing and exacerbation of asthma in a pediatric emergency unit (ED), comparing it to that recommended by the guidelines for this purpose.

METHODS: Descriptive cross-sectional study through medical records survey of children and adolescents ( 0 - 15 years of age) who received medication for wheezing or asthma exacerbation from January to April 2015 in the ED. The selected treatment was compared to that recommended by the guidelines, being analyzed the variables related to the medication (number and dose of short-acting $\beta 2$ agonist, associated or not with anticholinergic, oral or parenteral corticosteroid) and the length of stay in ED ( $\leq 1 \mathrm{~h}, \geq 8 \mathrm{~h}$ and hospital admission).

RESULTS: One-thousand eleven patients were selected with 56.7\% between 3 and 15 years and 56\% male. Although the selected drugs were in accordance with what was recommended, errors were observed in relation to dose, drug of choice, and method and time of use with the most frequent finding being incorrect dose (short-acting $\beta 2$ agonist: $66 \%$ and ipratropium bromide: 95.2\%).

CONCLUSION: The level of use of the measures recommended by the guidelines was low but compatible with other studies, leading to an increased risk of treatment failure and higher costs. Despite wide dissemination, the established concepts have not been sufficiently incorporated into clinical practice, suggesting the need for more effective educational actions for this process to occur.

KEYWORDS: Asthma. Respiratory sounds. Child. Adolescent. Emergency treatment.

\section{INTRODUCTION}

Asthma affects $1.8 \%-36.7 \%$ of the population in different countries. ${ }^{1,2}$ An international multicenter study showed a $16.6 \%$ prevalence of recurrent wheezing with $72.7 \%$ requiring emergency consultations. In Brasil, the registered rates were high and varied between $11.8 \%$ and $21.7 \% .^{3}$ In Santo André, asthma was observed in $24.3 \%$ of children aged $6-7$ years and in $19 \%$ of adolescents aged $13-14$ years ${ }^{4}$ and $60.7 \%$ of emergency visits. ${ }^{5}$

Asthma is still a frequent cause of hospitalization, morbidity, and high financial burden for families and the healthcare system. ${ }^{6}$ The current literature is controversial with regard to the explanation for the increase in emergency visits in recent decades, 
suggesting a possible relationship to urban growth in developing countries. ${ }^{7}$

In Brasil, a reduction in mortality in the more developed regions is occurring, and an increase in others in which low socioeconomic status, inadequate treatment, irregular follow-up, and less access by the population to the health system prevail. In most of these cases the ED is the only gateway in which prescriptions for inhaled corticosteroids (IC) and referral to specialists are low. ${ }^{7-9}$

Asthma crisis or exacerbation (AE) is an acute or subacute worsening of symptoms and lung function in relation to the patient's usual state and demonstrates inadequate control of the disease. Effective treatment is related to the rapid and accurate assessment of severity with a medical approach immediate, effective, and improved oxygenation..$^{7-11}$

The literature describes several risk factors for hospitalization and readmission: (1) age group $(<2$ years), (2) severity (moderate and severe persistent forms), (3) low socioeconomic status, (4) maternal education, (5) inadequate prophylactic treatment, and (6) most importantly, repeated consultations in the $\mathrm{ED}(\geq 2 \mathrm{x} /$ month $)$ in addition to asthma in close relatives, absence of follow-up, passive smoking, male gender, and school attendance of these patients. ${ }^{12,13}$

The objective of the study was to describe the treatment used and to assess whether the measures applied by pediatricians in the ED are in accordance with the guidelines for the proper management of $\mathrm{AE}$ and wheezing.

\section{METHODS}

This study was a cross-sectional descriptive study with data collection at the Bangu Emergency Care Unit, in Santo André, SP, which serves an urban population and users of the Unified Health System (SUS).

The medical records of children and adolescents from January to April 2015, were surveyed and included after fulfilling the inclusion criteria of age (zero and incomplete 15 years), with $\mathrm{AE}$ and/or wheezing, and who received a short-acting $\beta 2$ agonist (B2CA). Medical records showing failure to complete, doubtful diagnosis, and pathology in which the use of B2CA was not justified were excluded (Image 1). The length of stay was considered from the patient's arrival to the last medical or nursing note.
The unit of analysis was the visit to the ED as each visit represented an occasion for independent treatment.

To assess the adequacy of the treatment, we used the Global Initiative for Asthma (GINA) $2014^{10}$ and Guidelines of the Brazilian Society of Pulmonology and Tisiology for Asthma Management, 2012 ${ }^{11}$ as the guidelines for treatment assessment.

The variables that were analyzed related to medications were number of inhalations and dose of B2CA, isolated or associated with anticholinergic, use of corticosteroids and those related to the outcome included length of stay in $\mathrm{PE} \leq 1 \mathrm{~h}$ and prolonged stay $\geq 8 \mathrm{~h}$.

The drugs available at the time of the study were fenoterol, ipratropium bromide, corticosteroids (prednisone, prednisolone, hydrocortisone, methylprednisolone, and dexamethasone), magnesium sulfate, and aminophylline.

The ED did not have a peak expiratory flow meter.

To characterize the sample, descriptive statistical methods were used, and the results were transferred to a database, prepared in Excel (Microsoft), and analyzed with the STATA version 11.0 program. Qualitative variables were presented as absolute numbers and percentages. The level of significance was $5 \%$.

The study was approved by the Research Ethics Committee of the Faculdade de Medicina do ABC (Opinion Number: 2,647,797).

\section{RESULTS}

The consultations $(12,038)$ were carried out in the evaluation period with 1,497 patients receiving B2CA but only 1,011 diagnosed with $\mathrm{AE}$ or wheezing.

There was a predominance of males (573/1011; $56.7 \%)$ and the age group of 3 to 15 years (567/1011; $56 \%)$. They were divided according to the presentation of isolated wheezing $(609 / 1011 ; 60.2 \%)$, wheezing associated with viral disease $(217 / 1011 ; 21.5 \%)$ and wheezing associated with bacterial disease (185/1011; $18.3 \%$ ) (Table 1).

Although the selected drugs were in accordance with the recommended guidelines, with the exception of aminophylline, which was used in 14 (1.4\%) children, and magnesium sulfate, recommended in the most severe and refractory cases, was used only once, ${ }^{6,8-10,12}$ inconsistencies were observed regarding the form of use, dose, and length of stay: 
IMAGE 1. SELECTION OF MEDICAL RECORDS UNTIL SAMPLE IS OBTAINED.

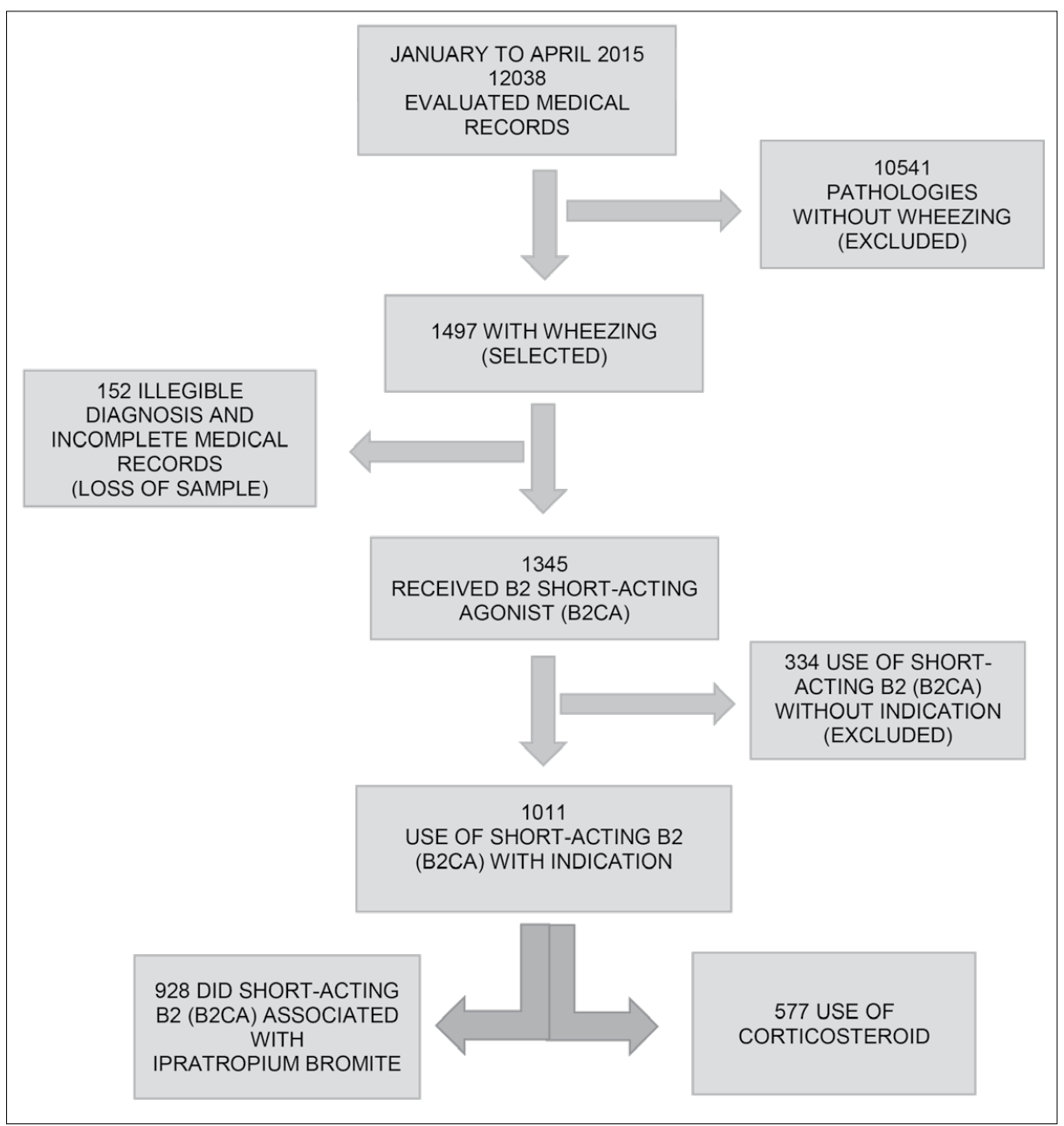

TABLE 1. DIAGNOSIS OF ADMISSION TO THE EMERGENCY DEPARTMENT (ED) ACCORDING TO AGE, RECOMMENDATIONS ABOUT THE USE OF THE SHORT-ACTING $\beta 2$ AGONIST, IPRATROPIUM BROMIDE, AND INADEQUATE NUMBER OF INHALATIONS (N=1011).

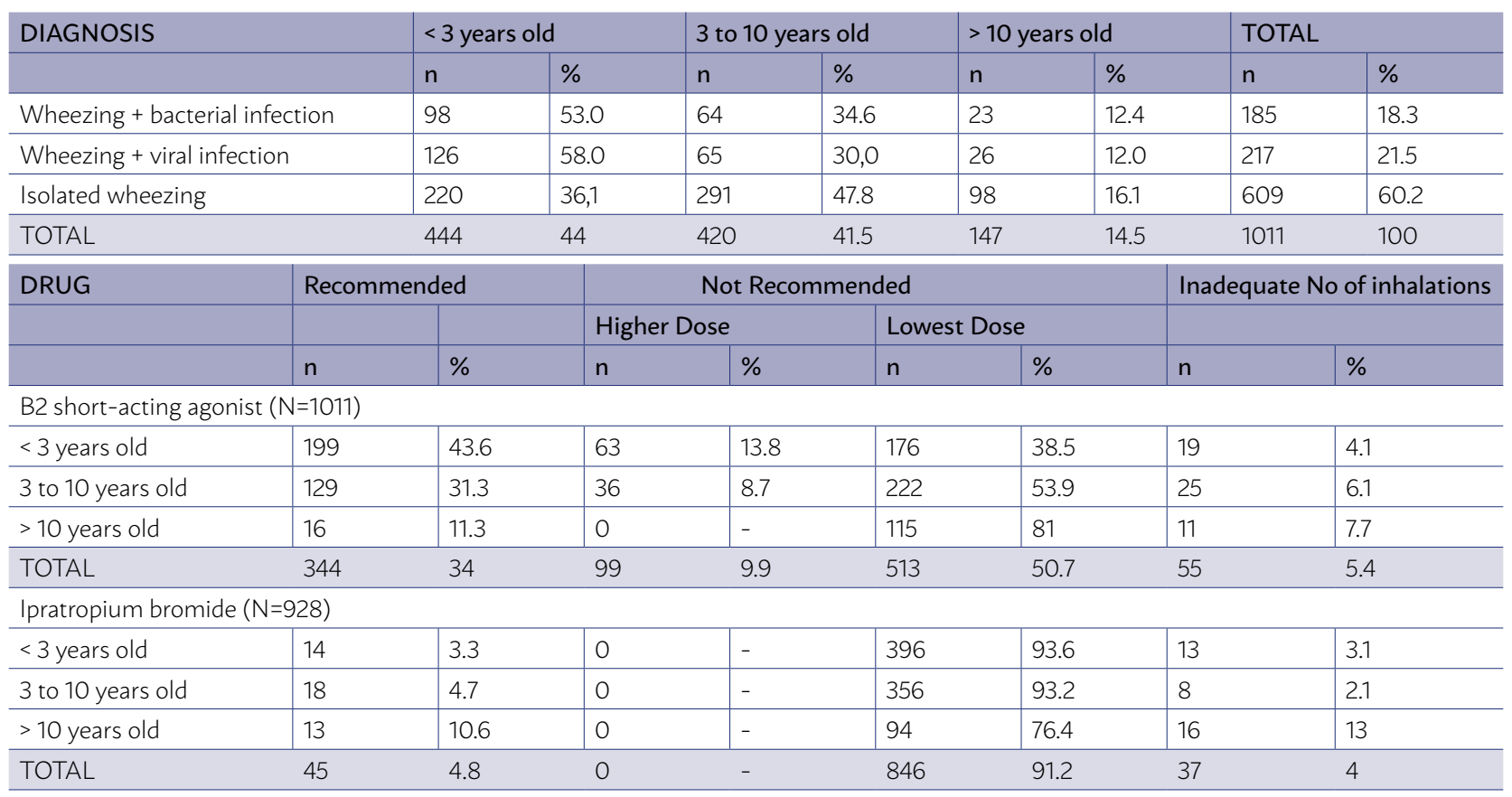


a. B2 short-acting agonist (B2CA): Fenoterol was the selected $\mathrm{B} 2 \mathrm{CA}$ via nebulization with $\mathrm{O}_{2}$ being the vehicle with $0.9 \%$ saline volume of $5 \mathrm{ml}$ without reference to the flow.

For this variable, 1011 (67.5\%) of the 1.497 patients were eligible because 152 (10.2\%) of the medical records were inadequate and 334 (22.3\%) of the children did B2CA without indication; of these eligible children, 344/1011 (34\%) received the doses that were recommended in the guidelines. Of the changes not recommended, we found low dose 513/1011 (50.7\%), above dose in 99/1011 (9.9\%), and inadequate inhalation number with $55 / 1011$ (5.4\%).

We then observed that $66 \%$ of the children received inadequate doses of $\mathrm{B} 2 \mathrm{CA}$ (Table 1).

b. Ipratropium bromide: In the study, 928/1011 (91.8 \%) received anticholinergic associated with B2CA although the recommendations in the guidelines state it should be used only in severe cases in the first three inhalations; of these 45/928 (4.8\%) received recommended doses, and for the vast majority 883/928 (95.2\%), there were errors regarding dose, severity, and/or number of inhalations (Table 1).

c. Corticosteroids: In the study 577/1011 (57\%) children received some corticosteroids, which were more frequent in the group of isolated wheezers 360/609 (59.1\%). Hydrocortisone was the most used with the preferred route being intravenous followed by the intramuscular route (Table 2).

d. Length of stay in the ED: Regarding the 1497 children who received $\beta 2 \mathrm{CA}$, two evasions (0.1\%), 101 (6.7\%) medical records without information about the medication schedules were noted. It was possible to analyze 1394 medical records regarding the length of stay. We found 502/1394 (36\%) who stayed $<1 \mathrm{~h}$ throughout their service, 496/1394 (35.6\%) from 1 to $2 \mathrm{~h}, 367 / 1394$ (26.3\%) from 2 to $8 \mathrm{AM}$, and $29 / 1394(2.1 \%)>8 \mathrm{~h}$. The vast majority $(71.6 \%)$ remained $<2 \mathrm{~h}$ in their care.

\section{DISCUSSION}

$\mathrm{AE}$ and wheezing are currently among the most frequent causes of visits to ED and hospitalization in the pediatric age group. ${ }^{2,4,6,7,9-11}$ This reality contrasts with implementation in the last decades of guidelines whose purpose is to update, guide, and standardize diagnostic and treatment procedures and consequently, obtain better control of the disease. ${ }^{6,9-13}$

The disclosure of guidelines, however, is not always sufficient to lead to their use in daily practice; therefore, there is a gap between the management of patients and the one recommended by the guidelines occurs. ${ }^{8,14,19,20}$ The recommendations are not even followed by doctors who understand them, which contributes to the occurrence of poor treatments, prescription errors, and poor maintenance of disease morbidity. ${ }^{14-18}$

Inadequate control and management in asthma attacks are associated with significant morbidity and economic impact. ${ }^{8,11,21,22}$ Analyzing and changing these barriers to adherence to the management and treatment guidelines are essential to improve disease management. 4,10,11,15

In wheezing, treatment, including B2CA, ipratropium bromide, IC, oral corticosteroid (OC), magnesium sulfate, and occasionally adrenaline in addition to theophylline within the scope of intensive care is recommended. 9,10,12 At the time of the study, salbutamol and IC recommended by the guidelines were not available in the ED, despite being provided free of charge by the Popular Pharmacy Program of the Ministry of Health/2012.9, 9,1,23,24

The present study showed a predominance of isolated wheezing in all age groups, a finding that was not compatible with the literature, which reports a higher incidence of viral and bacterial associations, especially in younger children. These data may be a consequence of the selected model, which did not allow patient follow-up and subsequent verification of the association in addition to the absence of supporting tests. ${ }^{10,19}$

TABLE 2. USE OF CORTICOSTEROIDS ACCORDING TO THE DIAGNOSIS OF PATIENTS.

\begin{tabular}{l|l|l|l|l|l|l|l|l} 
Corticosteroid & Wheezing + bacterial infection & Viral Wheezing & \multicolumn{2}{l}{ Isolated Wheezing } & TOTAL \\
\hline & $\mathbf{n}$ & $\%$ & $\mathbf{n}$ & $\%$ & $\mathrm{n}$ & $\%$ & $\mathrm{n}$ & $\%$ \\
\hline None & $\mathbf{4}$ & 17 & 111 & 25.6 & 249 & 57,4 & 434 & 43 \\
\hline Oral Route & 39 & 18.5 & 42 & 19.9 & 130 & 61.6 & 211 & 20,9 \\
\hline Intravenous Route & 29 & 14.6 & 31 & 15.6 & 138 & 69.8 & 198 & 19.5 \\
\hline Intramuscular Route & 43 & 25.6 & 33 & 19.6 & 92 & 54.7 & 168 & 16.6 \\
\hline TOTAL & 185 & 18,4 & 217 & 21,5 & 609 & 60,1 & 1011 & 100 \\
\hline
\end{tabular}


Several authors have observed the use of insufficient doses of B2CA in the ED. ${ }^{11,12,17,21}$ As in most public EDs in Brasil, fenoterol, rather than salbutamol, was available. Fenoterol is practically not mentioned in the current literature, whereas salbutamol has been widely used and studied in recent years. ${ }^{9-11,22}$

Corticosteroids are the gold standard for the treatment of AS and wheezing, and should be used in the first hour, being a well-documented fact that their use decreases visits to ED (25\%), ${ }^{17,19,22}$ hospitalizations, re-consultations, and severity. ${ }^{6,10,11}$ Its use is recommended orally as early as possible because regardless of the route chosen, it requires at least $4 \mathrm{~h}$ to observe clinical improvement. ${ }^{11,12,15,24,25}$ At the time of the study (2014/15) its use, route, and doses were well established. ${ }^{6,9-11}$ However, in this study, the preferred routes were intravenous and intramuscular, determining an increase on invasive procedures, material costs and hours of nursing, despite not having been reported clinical data that supported their prescription, such as vomiting or severity of the case. ${ }^{6,9-11}$ Oral prednisolone, recommended in the guidelines, was used in $211 / 576$ (36.6\%), and intramuscular dexamethasone in $58 / 576(10 \%)$. The prescribed dose was not analyzed due to the frequent lack of weight registration in the medical records, which was probably calculated by formulas. ${ }^{6,9-11}$ Although studies have shown that the dose does not have a big impact on emergency treatment, ${ }^{18}$ the use of recommended doses is of paramount importance when considering its adverse effects. ${ }^{6,9-11}$

Ipratropium bromide is an inhaled anticholinergic that when administered with B2CA decreases the risk of hospitalization in children with EA. ${ }^{23}$ Its use is well endorsed in EDs, especially in severe crises but not in hospitalized patients and in mild crises ${ }^{24}$ because it does not improve the severity of the case or decrease the length of hospital stay and generates unnecessary expense (three times greater than that of fenoterol). ${ }^{15,22-24}$ The combination of ipratropium bromide and B2CA produces marked and prolonged bronchodilation thus causing a decrease in secretions and edema in $\mathrm{AE}$ and wheezing. ${ }^{23,24}$ With regard to this variable, the greatest inconsistencies were found, demonstrating that there are barriers preventing guidelines from being used in clinical practice. It is worth mentioning that these drugs are the ones that suffered the most changes in the latest guidelines. ${ }^{8-11,23,24}$

The length of stay in the ED was difficult to assess due to the few information found in the medical records. It is also important to mention the impossibility of quantifying the waiting time to fill the form, screening by the nurse, and medical care, thus enabling the risk of bias. However, it is important to note that the early discharge of ED is known to be one of the main causes for re-consultations and complications, and this subject deserves further studies. ${ }^{15}$ A length of stay $<2 \mathrm{~h}$ for all care is considered as high risk for not following the protocols as studies recommend the observation of at least $1 \mathrm{~h}$ after adequate response to treatment to consider the condition stable and opt for discharge. ${ }^{10,11,15}$

According to the medical records, 998/1394 (71.6\%) children could have an unfavorable prognosis due to the short observation period. However, the shorter time in ED suggests that AE were considered mild or moderate when the number of inhalations would be less than three or that there was an error in the diagnosis or classification. These findings are in line with the literature in which it is reported that mild crises are the most neglected with the need to emphasize the recommendations for valuing symptoms and early identification of warning signs and worsening as reported by the family. ${ }^{8-11}$

Studies show that knowledge about AE is insufficient and is worrying among ED professionals ${ }^{19,20}$ and point to flaws and barriers in adhering to the guidelines with underuse of medications and misguided clinical conduct that increase the risk of serious and fatal crises. In addition, attitudes are incorporated into clinical practice that hinder the applicability of guidelines in addition to the lack of appropriate drugs and structural and functional changes in the public service..$^{14,17,18}$

In Brasil, nebulization is still the most widely used form of inhaled drug administration. Studies have demonstrated equivalence or advantages of aerosols, associated or not with spacers, which lead to rapid onset bronchodilation (1-5 min) with lasting therapeutic effects of 2 to $6 \mathrm{~h}$, ease of administration, less side effects, better lung deposition, faster preparation and administration (Nebulization $= \pm 13.8 \mathrm{~min}$; ID $= \pm 3.4$ minutes), and lower cost (Nebulization $= \pm R \$ 15.7$; ID $= \pm R \$ 4,7)$, representing $30.3 \%$ of the cost of nebulization, but this comparison did not take into account the disinfection cost for reusing the spacers that would be necessary in the emergency room. ${ }^{8-11,15,19,22}$

As for the cost of prophylactic treatment with inhaled corticosteroids and clinical follow-up (6 consultations/year) in Brasil, it is equivalent to a single hospitalization $(\mathrm{U} \$ 120,00)$, considering only the direct cost. $^{14}$ 
In the present study, the use of B2CA and non-recommended ipratropium bromide was observed, especially with doses below the recommended ones, corticosteroids by non-recommended routes, use of aminophylline to the detriment of magnesium sulfate, and remaining under observation for a shorter time than indicated, facts that can determine unfavorable consequences.

Aiming at reducing $\mathrm{AE}$ and wheezing related morbidity, current knowledge highlights the importance of adopting a set of prophylactic measures, such as: exclusive breastfeeding, avoiding exposure to viruses, at least in the first three months of life (maternity leave), adequate vaccination; assistance: adequate and judicious use of drugs with procedures adapted to our actual situation; managerial: reduction in treatment costs, impact on the drug-based economy and educational aspects with the implementation of teaching strategies for caregivers and health professionals in prevention, diagnosis, treatment and dissemination of this knowledge. ${ }^{8,9,17}$

\section{CONCLUSION}

The level of use of the measures recommended by the guidelines was low and compatible with other studies, leading to an increase in the risk of treatment failure and higher cost.

It is concluded that there is a need to promote effective and continuous education of health professionals in the ED for better understanding and adherence to the recommendations elaborated by the guidelines, which despite their wide dissemination, are poorly implemented in clinical and daily practice.

\section{Author's Contribution}

All authors have contributed equal to work.

\section{RESUMO}

OBJETIVOS: Avaliar o tratamento da sibilância e da exacerbação da asma em unidade de emergência pediátrica (DE), comparando-o ao recomendado pelas diretrizes para esse fim.

MÉTODOS: Estudo descritivo transversal, por meio do levantamento de prontuários de crianças e adolescentes ( 0 - 15 anos de idade) que receberam medicação para sibilância ou exacerbação da asma, no período de janeiro a abril de 2015, em DE. O tratamento empregado foi comparado ao preconizado pelas diretrizes sendo analisadas as variáveis referentes à medicação (número e dose de $\beta 2$ agonista de curta ação, associado ou não a anticolinérgico, corticosteroide oral ou parenteral) e ao tempo de permanência na DE ( $\leq 1 \mathrm{~h}, \geq 8 \mathrm{~h}$ e internação hospitalar).

RESULTADOS: Foram selecionados 1011 pacientes, 56,7\% com idades entre 3 e 15 anos e 56 \% do sexo masculino. Embora os fármacos utilizados estivessem de acordo com o preconizado, foram observados erros com relação a dose, droga de escolha, forma de utilização, tempo de uso, sendo dose incorreta o achado mais frequente ( $\beta 2$ agonista de curta ação: 66\% e brometo de ipratrópio: 95,2\%).

CONCLUSÃo: O nível de utilização das medidas recomendadas pelas diretrizes foi baixo e compatível com outros estudos, levando a risco aumentado de falha no tratamento e maior custo. Apesar da ampla divulgação, os conceitos estabelecidos não são suficientemente incorporados à prática clínica, sugerindo a necessidade de ações educativas mais efetivas para que isso ocorra.

PALAVRAS-CHAVE: Asma. Sons respiratórios. Criança. Adolescente. Tratamento de emergência.

\section{REFERENCES}

1. Worldwide variation in prevalence of symptoms of asthma, allergic rhinoconjunctivitis, and atopic eczema: ISAAC. The International Study of Asthma and Allergies in Childhood (ISAAC) Steering Committee. Lancet. 1998; 351:1225-30.

2. Solé D, Camelo-Nunes I, Wandalsen GF, Mallozi MC. Asthma in children and adolescents in Brasil: contribution of the International Study of Asthma and Allergies in Childhood (ISAAC). Rev Paul Pediatr 2014; 32:114-25.

3. Mallol J, Solé D, Garcia-Marcos L, Rosario N, Aguirre V, Chong H, et al. Prevalence, Severity, and Treatment of Recurrent Wheezing During the First Year of Life: A Cross-Sectional Study of 12,405 Latin American Infants. Allergy Asthma Immunol Res 2016; 8:22-31.

4. Solé D, Wandalsen GF, Camelo-Nunes IC, Naspitz CK. ISAAC - Brazilian Group. Prevalence of symptoms of asthma, rhinitis, and atopic eczema among Brazilian children and adolescents identified by the International Study of Asthma and Allergies in Childhood (ISAAC) - Phase 3. I Pediatr (Rio J). 2006; 82:341-46.
5. Ferreira IC, Wandalsen NF. Prevalence and severity of wheezing in the first year of life in the city of Santo André, Brasil. Rev Paul Pediatr 2014; 32:164-70.

6. Sociedade Brasileira de Pneumologia e Tisiologia. IV Diretrizes Brasileiras para o Manejo da Asma. J Bras Pneumol 2006;32: S447-S474.

7. Souza-Machado C, Souza-Machado A, Cruz AA. Asthma mortality inequalities in Brasil: Tolerating the unbearable. Scientific World J 2012.

8. Lustosa GM, Britto MC, Bezerra PG. Acute asthma management in children: knowledge of the topic among health professionals at teaching hospitals in the city of Recife, Brasil. J Bras Pneumol 2011; 37:584-88.

9. Chong Neto HI, Solé D, Wandalsen NF, Wandalsen GF, Sano F, Kiertsman B, et al. Diretrizes da Associação Brasileira de Alergia e Imunologia e Sociedade Brasileira de Pediatria para sibilância e asma no pré-escolar. Allergy Asthma Immunol Res. 2018; 2018:

10. Global Initiative for Asthma - GINA [homepage on the Internet]. Bethesda: 
Global Initiative for Asthma. [cited 2011 Apr 1] Global Strategy for Asthma Management and Prevention, 2014.

11. Sociedade Brasileira de Pneumologia e Tisiologia. Diretriz da Sociedade Brasileira de Pneumologia e Tisiologia para o Manejo da Asma. J Bras Pneumol 2012;38: S1-S46.

12. Lasmar L, Goulart E, Sakurai E, Camargos P. Fatores de risco para hospitalização de crianças e adolescentes asmáticos. Rev. Saúde Pública [online]. 2002; 36:409-19. ISSN 0034-8910.

13. Wever-Hess J, Kouwenberg JM, Duiverman EJ, Hermans J, Wever AMJ Risk factors for exacerbations and hospital admissions in asthma of early childhood.Pediatr Pulmonol 2000;29:250-56.

14. Cabana MD, Rand CS, Becher OJ, Rubin HR. Reasons for pediatrician nonadherence to asthma guidelines, Arch Pediatr Adolesc Med. 2001;155:1057-1062

15. Ducharme FM, Zemek, R, Chuahan BF, Gravel J, Chalut D, Poonai N, et al. Factors associated with failure of emergency department management in children with acute moderate or severe asthma: a prospective, multicentre, cohort study. Lancet Respir Med 2016; 20: S2213-2600(16)30160-6. Published online 2016 Jul 20.

16. Lasmar L, Goulart E, Sakurai E, Camargos P. Fatores de risco para readmissão hospitalar de crianças e adolescentes asmáticos. J. Bras Pneumol [online]. 2006; 32:391-99.

17. Cordeiro NGB; José LA, Cunha A, Chigres Kuschnir F. Conhecimento sobre asma de pediatras de hospitais públicos do Rio de Janeiro. Arq asma Alerg Imunol 2018; 2:108-15.
18. Chong Neto HJ. Crise aguda de asma em crianças na emergência: estamos seguindo as diretrizes? Arq asma Alerg Imunol 2018; 2:5-6.

19. Santos AP, De Lima LS, Wanderley AG. Comparison between the drug treatment used in children up to five years of age treated in an emergency room and the guidelines established in the III Brazilian Consensus on Asthma Management. | Bras Pneumol 2007; 33:7-14

20. Cunningham S, Logan C, Lockerbie L, Dunn MJ, McMurray A, Prescott RJ. Effect of an integrated care pathway on acute asthma/wheeze in children attending hospital: cluster randomized trial. | Pediatr 2008;152: 315-20

21. Damasceno E, Costa-Carvalho BT, Solé D, Wandalsen GF. Custos diretos e indiretos da asma: revisão de literatura. Rev. Bras. Alerg. Imunopatol. 01032259/12/35-06/234 (2012).

22. Cardozo CA, Chong Neto HJ, Olandoski M, Noronha L. Custo total do tratamento da crise aguda de asma em crianças utilizando diferentes dispositivos inalatórios. Rev Bras Alerg Imunopatol 2006; 06/29-02/100.

23. Griffiths B, Ducharme FM. Combined inhaled anticholinergics and short-acting beta2-agonists for initial treatment of acute asthma in children. Cochrane Database Syst Rev 2013; (8): CD0000608:CD000060

24. Vezina K, Chauhan BF, Ducharme FM. Inhaled anticholinergics and short-acting (2)-agonists versus short-acting (2)-agonists alone for children with acute asthma in hospital. Cochrane Database Syst Rev 2014;(7):CD010283

25. Brasil Ministério da Saúde. Portaria-1317- DE 25 DE NOVEMBRO DE 2013bvsms.saude.gov.br/bvs/saudelegis/sas/2013/prt1317_25_11_2013.html 